\title{
Strategi Pemasaran dalam Membangun Brand Image Pada Sekolah Aluna Montessori Jakarta
}

\author{
Yuli Purnamasari ${ }^{1}$, Veronika Setyadji ${ }^{2}$, Shulhuly Ashfahani ${ }^{3}$ \\ ${ }^{1,2,3}$ Sekolah Tinggi Ilmu Komunikasi Indonesia Maju \\ Email correspondent: yulipurnamasari088@gmail.com
}

\begin{abstract}
Abstrak
Sekolah Aluna merupakan salah satu sekolah berbasis inklusi yang dibutuhkan oleh anak berkebutuhan khusus. Namun saat ini Sekolah Aluna mengalami penurunan jumlah siswa/i yang disertai dengan menurunnya brand image di masyarakat, walaupun sekolah ini telah melaksanakan layanan dan promosi dengan baik. Tujuan dari penelitian ini untuk mengetahui strategi promosi yang digunakan Sekolah Aluna dalam membangun brand image. Peneliti menggunakan metode deskriptif kualitatif dengan pendekatan studi kasus. Jenis dan teknik pengumpulan data adalah data primer yang diperoleh dari wawancara serta data sekunder diperoleh dari data yang berbentuk buku, web, dan dokumentasi. Teknik analisa yang digunakan dalam penelitian ini merangkum data, menyajikan data dan menyimpulkan data tersebut. Hasil penelitian bahwa Sekolah Aluna perlu meningkatan pelayanan dan memperbaharui strategi promosi (brosur, spanduk, media sosial: facebook dan instagram) serta pendekatan hubungan masyarakat (public relations) supaya meningkatkan jumlah siswa serta meningkatkan brand image. Penurunan jumlah siswa dan brand image Sekolah Aluna dapat diperbaiki dengan cara memperbaharui promosi berupa brosur, spanduk, website serta melakukan pelatihan sumber daya manusia supaya lebih memahami layanan jasa yang ditawarkan dan informasi yang disampaikan lebih informatif.
\end{abstract}

Kata Kunci: sistem dan metode pembelajaran, promosi, brand image

\begin{abstract}
Aluna School is based on inclusion one of the requirements of children with special needs. However, currently, Aluna School has experienced a fall in the number of students that have been accompanied by a decrease in the city the brand image amid society, even though this school has implemented good promotion and service. The purpose of this research is to know a strategy of promotion used by Aluna School in building the brand image. Researchers used a method of descriptive qualitative with the approach of a case study. Type and technique data collection is primary data obtained from the interviews, while secondary data is obtained from the data shaped book, web, and documentation. Technique data analysis used in the research summarized data provides the data and concluded the data. The research results that the school Aluna needs to increase service and the promotional strategy (brochures, banners, social media: Facebook and Instagram) approach as well as public relations to increase the number of students as well as brand image. The number of students and the brand image of Aluna School can be improved by way of brochures renew promotion, banners, website, and conduct training human resources so as understand the service offered and the information disseminated circulation of more informative.
\end{abstract}

Keywords: the system and a method of learning, promotion, brand image 


\section{Pendahuluan}

Pendidikan dibutuhkan oleh setiap anak dalam pembentukan karakter anak untuk itu pendidikan sebagai sarana proses pembentukan pribadi, pendidikan diartikan sebagai suatu kegiatan yang sistematis (berlangsung melalui tahap-tahap bersinambungan) dan sistemik (semua situasi kondisi, di semua lingkungan yang saling mengisi baik lingkungan rumah, sekolah, dan masyarakat) terarah kepada terbentuknya kepribadian peserta didik. ${ }^{1}$ Sebagaimana yang pernah diungkapkan oleh Ki Hajar Dewantara, bahwa pendidikan berarti daya upaya untuk memajukan pertumbuhan budi pekerti dan pikiran anak supaya tumbuh selaras dengan kehidupan supaya mampu memberikan penghidupan untuk anak tersebut. ${ }^{2}$ Pondasi awal dalam pembentukan karakter pun berada pada anak usia dini sebelum anak memasuki jenjang/tingkat sekolah lebih tinggi melalui pendidikan, budi pekerti, pikiran dibentuk dari sedini mungkin karena masa emas (golden age) berada pada tingkat pendidikan usia dini.

Pendidikan diberikan bukan hanya untuk anak normal/reguler saja akan tetapi anak berkebutuhan khusus juga memiliki hak pendidikan yang sama. Sesuai dengan Peraturan Menteri Pendidikan No. 70 Tahun 2009 yang menyatakan pendidikan inklusi adalah sistem penyelenggaraan pendidikan yang memberikan kesempatan kepada semua peserta didik yang memiliki kelainan dan memiliki potensi kecerdasan dan atau bakat istimewa untuk mengikuti pendidikan atau pembelajaran dalam satu lingkungan pendidikan secara bersama-sama dengan peserta didik pada umumnya. Pendidikan inklusi merupakan pergeseran dari kecemasaan tentang suatu kelompok tertentu menjadi upaya yang difokuskan untuk mengatasi hambatan untuk belajar dan berpartisipasi. ${ }^{3}$

Anak-anak berkebutuhan khusus memerlukan dukungan guna mengatasi kesulitan belajar serta perhatian yang lebih dalam proses belajar mengajar. Hal ini mungkin menandakan diperlukannya keterlibatan dan penilaian guru kelas serta koordinator anak berkebutuhan khusus (shadow teacher) dalam pembuatan rencana pendidikan individu (RPI) yang bersifat individual yang sudah ditetapkan target dan akan ditinjau secara berkala. ${ }^{4}$ Sistem pendidikan inklusi digunakan dalam menangani anak berkebutuhan khusus untuk mengembangkan anak tersebut menjadi mandiri serta dapat mengikuti kegiatan sekolah pada umumnya. Namun, saat ini tidak banyak sekolah yang memberikan sistem seperti itu, apalagi untuk anak usia dini. Padahal anak berkebutuhan khusus memerlukan sekolah dengan sistem inklusif ini supaya menumbuhkan empati (perasaan mengalami hal yang sama) dari seluruh elemen sekolah terhadap anak berkebutuhan khusus tersebut.

Pendidikan anak usia dini merupakan pendidikan yang awal dalam perkembangan anak di masa selanjutnya sangat ditentukan oleh berbagai stimulasi bermakna yang diberikan sejak usia dini. Pendidikan anak usia dini harus dipersiapkan secara terencana dan bersifat holistik-integratif agar di masa emas perkembangan anak mendapatkan stimulasi yang utuh, untuk mengembangkan berbagai potensi yang dimilikinya. ${ }^{5}$ Pendidikan yang diberikan kepada anak di usia dini hendaknya lebih bersifat arahan bukan larangan, seperti memberikan ruang gerak yang luas kepada anak di usia dini dapat membantu pertumbuhan motorik anak yang sedang berkembang. Memberikan permainan yang edukatif dan kesempatan untuk membuat suatu kerajinan atau prakarya pada anak juga dapat membantu mengembangkan potensi yang dimilikinya.

Menurut Carl I. Hovland, komunikasi adalah proses yang memungkinkan seseorang (komunikator) menyampaikan rangsangan (biasanya lambang-lambang verbal) untuk mengubah perilaku orang lain (komunikate). ${ }^{6}$ Proses komunikasi dalam pendidikan berjalan lancar bukan hanya dilihat dari sistem ataupun metode pembelajarannya saja akan tetapi dari segi promosi yang dilakukan instansi pendidikan/sekolah tersebut. Kegiatan promosi bukan hanya berfungsi sebagai alat komunikasi antara perusahaan/instansi kepada konsumen, melainkan juga sebagai alat untuk mempengaruhi konsumen dalam kegiatan pembelian atau penggunaan jasa sesuai dengan keinginan dan kebutuhannya. ${ }^{7}$

Sekolah merupakan wadah pendidikan yang memberikan pelayanan untuk semua lapisan masyarakat, baik sekolah negeri maupun swasta. Sekolah negeri dibawah naungan pemerintah tidak terlalu melakukan promosi, sedangkan sekolah swasta harus melakukan promosi agar menarik minat orang tua calon peserta didik. Promosi yang dilakukan sekolah seperti memasang baliho, menyebarkan pamflet, dan memasang iklan ataupun mengunduh kegiatan sekolah yang menarik di berbagai media 
sosial. Promosi dapat dilakukan dengan memberikan harga yang terjangkau dan memiliki kualitas pendidikan yang baik. Promosi dilakukan supaya orang tua dari calon peserta didik mengetahui sarana dan prasarana dalam menunjang kegiatan belajar di sekolah. Promosi dengan desain brosur yang menarik dapat menarik minat orang tua calon peserta didik untuk mendapatkan pendidikan di sekolah tersebut serta ingin memberikan pendidikan yang terbaik untuk anak mereka.

Michael Ray dalam Morissan mendefinisikan promosi merupakan koordinasi dari seluruh upaya yang dimulai pihak penjual untuk membangun berbagai saluran informasi dan persuasi untuk menjual barang dan jasa atau memperkenalkan suatu gagasan. ${ }^{8}$ Promosi memiliki tujuan menyebarluaskan informasi mengenai suatu produk atau jasa kepada calon konsumen agar menarik minat untuk menggunakan produk atau jasa tersebut serta agar terciptanya pembelian yang berkelanjutan. Perusahaan produk ataupun jasa melakukan aktivitas pemasaran secara terpadu memiliki empat komponen yaitu, produk, harga, promosi, dan tempat. Kegiatan promosi yang dilakukan dapat membangun citra merek dari suatu produk ataupun jasa. Promosi yang dilakukan selain untuk mengajak calon konsumen untuk membeli juga digunakan untuk memperkenalkan citra merek kepada calon konsumen.

Kotler dan Keller dalam Priansa menyatakan bahwa citra merek adalah tanggapan konsumen pada keseluruhan penawaran yang diberikan oleh perusahaan. Citra perusahaan dapat dipahami juga sebagai sejumlah kepercayaan, dan kesan pelanggan kepada perusahaan. ${ }^{9}$ Hal ini dalam upaya meningkatkan citra baik terhadap customer. Brand image/citra merek adalah persepsi pelanggan tentang sebuah merek, yang tercermin dari asosiasi merek yang diadakan di memori pelanggan. ${ }^{10}$ Seseorang dapat mengingat hal-hal yang menyenangkan untuk dirinya, apalagi untuk pemilihan produk yang akan digunakan, baik barang ataupun jasa. Produk tersebut akan membekas di benak pelanggan tersebut secara baik ataupun buruk tergantung dari produk itu sendiri.

Sekolah Aluna merupakan salah satu sekolah dengan sistem inklusi dan menggunakan metode pembelajaran Montessori. Sekolah Aluna dengan sistem pendidikan inklusi yaitu menggabungkan antara anak reguler dengan anak berkebutuhan khusus, anak berkebutuhan khusus yang ditangani Sekolah Aluna khusus anak tunarungu atau mengalami gangguan pendengaran. Anak tunarungu di Sekolah Aluna menggunakan alat bantu dengar,karena di Sekolah Aluna mengedepankan untuk peserta didik dapat berkomunikasi secara verbal. Bahasa verbal bagi anak tunarungu atau mengalami gangguan pendengaran dapat diperoleh dari teman sebaya di kelas maupun lingkungan sekitar sekolah. Sistem pendidikan inklusi yang diterapkan di Sekolah Aluna membantu anak tunarungu untuk bersosialisasi dengan anak-anak regular yang sebaya maupun dengan orang dewasa di lingkungan sekitarnya. Adapun metode pembelajaran yang diterapkan di Sekolah Aluna yaitu menggunakan metode Montessori yang mengedepankan kemandirian anak dalam memilih serta melakukan hal yang diinginkan. Metode ini cocok untuk anak usia dini karena anak bebas mengeksplorasi material atau permainan edukasi tersebut. Metode Montessori merupakan suatu metode pembelajaran yang disebarluaskan oleh Maria Montessori pada tahun 1909 di Italia dengan menggunakan material atau permainan edukasi dalam penyampaian pembelajarannya.

Sekolah yang didirikan sejak 5 tahun yang lalu ini terus mengupayakan perkembangan pendidikan demi anak-anak tunarugu yang ingin mengenyam pendidikan yang sama dengan anak reguler pada umumnya. Akan tetapi, di tengah persaingan global seperti saat ini membuat Sekolah Aluna harus bekerja keras dalam memperbaiki dan mengembangkan promosi atau pemasaran sekolah. Promosi yang dilakukan Sekolah Aluna melalui media cetak seperti brosur belum informatif dan spanduk yang diletakan dekat lingkungan sekolah serta promosi melalui media sosial seperti facebook dan instagram juga belum efektif. Selain itu, admin sebagai salah satu public relations dari Sekolah Aluna belum menguasai informasi yang akan disampaikan kepada calon orang tua siswa karena admin yang terkadang berganti-ganti. Promosi yang dilakukan Sekolah Aluna tersebut dimaksudkan untuk membangun citra diri Sekolah Aluna supaya dikenal masyarakat sehingga dapat meningkatkan jumlah siswa atau peserta didik yang ada di Sekolah Aluna.

Berbagai kegiatan dan upaya yang dilakukan Sekolah Aluna dalam mempromosikan program- 
program sekolah supaya dikenal di masyarakat luas. Beberapa program Sekolah Aluna seperti Senin Bugar, Rabu Kreasi, Kamis Ceria, Pentas Seni di luar lingkungan sekolah serta seminar-seminar Montessori ataupun alat bantu dengan yang berkerja sama dengan pihak lain sesuai bidangnya. Selain itu,brosur, spanduk, serta berbagai media sosial seperti facebook dan instagram juga menjadi sarana untuk mempromosikan program-program yang ada di Sekolah Aluna. Disamping itu, Sekolah Aluna juga mulai membuka les-les khusus seperti les baca tulis, tarian tradisional, dan matematika menggunakan metode Montessori. Hal ini dilakukan dalam upaya Sekolah Aluna dapat bersaing dengan sekolah-sekolah yang lain.Sekolah Aluna memiliki motto bahwa "sekolah untuk semua". Selain dari metode pembelajarannya motto ini pun menjadi salah satu daya tarik bagi orang tua untuk menyekolahkan anaknya di Sekolah Aluna, supaya anak memiliki moral, kepribadian, ataupun karakter yang baik tanpa mengenal status sosial.

Tujuan penelitian ini ingin mengetahui strategi pemasaran yang akan dilakukan untuk membangun brand image tersebut.

\section{Metode}

Penelitian ini menggunakan pendekatan kualitatif yaitu pendekatan yang digunakan untuk meneliti pada kondisi obyek yang alamiah dimana peneliti adalah instrumen kunci. ${ }^{11}$ Peneliti sebagai instumen kunci mencari informasi dari berbagai sumber dengan melakukan observasi, wawancara, serta dokumentasi di Sekolah Aluna yang terkait dengan strategi promosi yang dilakukan dalam membangun brand image. Penelitian dengan pendekatan studi kasus berupaya menelaah sebanyak mungkin data mengenai subyek yang diteliti secara mendalam serta menyeluruh. Menurut Lincoln dan Guba dalam Fitrah \& Luthfiyah bahwa suatu penelitian dapat disebut sebagai penelitian studi kasus apabila diproses penelitiannya dilakukan secara mendalam dan menyeluruh terhadap kasus yang diteliti, serta mengikuti struktur studi kasus yaitu permasalahan, konteks, isu, dan pelajaran yang dapat. ${ }^{12}$

Penelitian dilaksanakan pada Sekolah Aluna yang beralamat Jalan Kebagusan Dalam IV No. 34 A Kecamatan Pasar Minggu Jakarta Selatan pada tanggal 24 Juni sampai dengan 30 Agustus 2019 untuk mengetahui strategi promosi dalam membangun brand image pada Sekolah Aluna Montessori Jakarta. Penelitian ini memiliki subjek yaitu keyinforman dan informan yang terdiri dari koodinator guru, guru, administrasi sekolah, serta orang tua murid untuk memperoleh data sebenarnya yang mengarah pada peristiwa/isu telah berlangsung/sedang berlansung dalam strategi pemasaran untuk membangun brand image Sekolah Aluna. Sumber data diperoleh dari data primer diperoleh langsung dari subyek penelitian seperti dari hasil wawancara dengan koordinator guru, guru, dan orang tua murid. Data sekunder merupakan data yang didapatkan peneliti dari semua sumber yang sudah ada seperti jurnal buku, laporan, artikel, buku dan lain sebagainya. Data sekunder ini diperoleh dari dokumen - dokumen sekolah yang berupa sejarah sekolah, visi, misi, dan data yang berkaitan dengan strategi promosi dalam membangun brand image di Sekolah Aluna. ${ }^{13}$

Metode pengambilan data yang dilakukan dalam penelitian ini meliputi wawancara, observasi, dan dokumentasi. Menurut Sugiyono mengemukakan beberapa macam wawancara, yaitu wawancara terstruktur, wawancara semiterstruktur, dan wawancara tak terstruktur. ${ }^{12}$ Penelitian ini digunakan wawancara semi terstruktur dan wawancara tidak terstruktur yang bertujuan untuk mendapatkan informasi awal mengenai strategi promosi dalam membangun brand image di Sekolah Aluna. Menurut Miles dan Huberman dalam Fitrah \& Luthfiyah terdapat tiga teknik analisis data kualitatif yaitu reduksi data, penyajian data dan penarikan kesimpulan. ${ }^{12}$ Reduksi/pengumpulan/merangkum data pada penelitian ini berupa hasil wawancara dengan koordinator guru, guru, administrasi sekolah serta wali murid Sekolah Aluna terkait dengan strategi promosi dalam membangun brand image. Tahap selanjutnya adalah melakukan penyajian data berupa teks yang bersifat narati supaya dalam penyajian data ini mempermudah untu memahami tentang strategi promosi dalam membangun brand image di Sekolah Aluna.

Penyajian data telah dilakukan dalam proses analisis data kualiatif maka selanjutnya dilakukan proses penarikan kesimpulan. Proses ini dilakukan dalam penelitian kualitatif untuk menjawab rumusan 
masalah yang telah dikemukan, seperti halnya dalam penelitian ini penarikan kesimpulan untuk menjawab strategi promosi dalam membangun brand image di Sekolah Aluna.

\section{Hasil dan Pembahasan}

Sistem pendidikan inklusi meupakan konsep pendidikan yang tidak membeda- bedakan latar belakang kehidupan anak karena terbatasan fisik maupun mental, serta menyamaratakan pendidikan untuk anak berkebutuhan khusus juga anak reguler/normal supaya merasakan pendidikan yang sama. ${ }^{14}$ Sistem inklusi merupakan salah sistem pembelajaran menggabungkan antara anak normal/reguler dengan anak berkebutuhan khusus. Salah satu sekolah yang menerapkan sistem pembelajaran ini yaitu Sekolah Aluna. Sistem pembelajaran ini bertujuan untuk membangkitkan rasa empati sejak dini. Sekolah Aluna pun melakukan penggabungan usia untuk tiap kelasnya terdiri dari kelas Tunas 1,5 tahun - 3 tahun, Kuncup 3 - 5 tahun, dan Mekar 5 - 7 tahun.

Selain penerapan sistem inklusi, Sekolah Aluna juga menggunakan metode Montessori dalam pengajarannya. Metode Montessori merupakan metode pembelajaran yang menerapkan tiga konsep yaitu follow the child (mengikuti anak), freedom with limitation (kebebasan berbatas), dan respect the child (menghargai anak). ${ }^{15}$ Sistem dan metode pembelajaran yang diterapkan di sekolah menjadi salah satu pemilihan pendidikan yang akan diambil oleh orang tua siswa. Sekolah Aluna sudah memiliki produk yang baik dan cukup menjadi nilai jual, namun tidak cukup sampai pada produk yang baik saja. Sekolah harus memiliki promosi dalam menyebarluhaskan keberadaan sekolah dengan sistem dan metode yang sedang dicari tersebut.

Beberapa faktor yang menjadi pertimbangan Sekolah Aluna untuk menyusun strategi promosi, yaitu terdiri dari $7 \mathrm{P}$ (product, price, promotion, place, people, process dan physical evidence) dalam bauran pemasaran yang dapat mempengaruhinya, antara lain sebagai berikut. ${ }^{16}$ Produk Sekolah Aluna adalah jasa program pendidikan dengan sistem pembelajaran berbasis inklusi dan menggunakan metode pembelajaran Montessori. Sekolah Aluna yang merupakan penggabungan antara anak reguler dengan anak berkebutuhan khusus.

Sekolah Aluna memiliki kelebihan dari segi produk yang ditawarkan, seperti layanan pendidikan inklusi (cocok untuk anak berkebutuhan khusus) dan metode pembelajaran yang sedang dicari orang tua siswa. Hal ini bisa dijadikan salah satu nilai jual Sekolah Aluna kepada konsumen karena memiliki produk yang sedang dicari oleh calon orang tua siswa. Price (biaya) saat ini pendidikan memerlukan biaya yang cukup banyak, apalagi untuk anak berkebutuhan khusus yang memerlukan penanganan yang tidak biasa, pastilah biaya menjadi beberapa hal utama. Biaya sekolah di wilayah Jakarta cukup tinggi, membuat Sekolah Aluna ingin memfasilitasi pendidikan usia dini khususnya untuk anak berkebutuhan khusus yang memiliki ekonomi prasejahtera untuk ikut merasakan pendidikan.

Sekolah dengan motto "Sekolah Untuk Semua" menegaskan bahwa sekolah usia dini ini bisa untuk semua kalangan, semua lapisan masyarakat, semua anak baik anak reguler maupun anak berkebutuhan khusus. Sekolah Aluna memberikan biaya sekolah yang cukup tinggi untuk anak dengan orang tua berlatar belakang mampu karena hal ini untuk mensubsidi anak-anak dari kalang prasejahtera untuk ikut merasakan pendidikan usia dini yang memiliki layanan pendidikan berkualitas.

Selain produk dan biaya yang menjadi bahan pertimbangan, letak/lokasi tempat usaha menjadi faktor penentu dalam mempertimbangan pemilihan sekolah. Sekolah Aluna memiliki lokasi di tengah perumahan yaitu di Jalan Kebagusan Dalam IV No. 34 A dekat dengan masyarakat baik kalangan prasejahtera maupun menengah atas ada di sekitar Sekolah Aluna. Sekolah Aluna juga memiliki day care yang difungsikan untuk anak-anak yang orang tuanya bekerja. Jadi para orang tua tidak perlu merasa khawatir jika memang belum ada pengasuh di rumah mereka. Anak mereka dapat dititipkan di day care sampai mereka pulang bekerja.

Promosi yang dilakukan oleh Sekolah Aluna menggunakan media offline (brosur dan spanduk) dan online (website, media sosial: facebook dan instagram). Media offline yang digunakan Sekolah Aluna harus adanya pembaharuan karena sudah terlihat usang (spanduk) dan desain yang ditampilkannya pun kurang menarik seperti pemilihan warna yang kurang sesuai dengan sekolah untuk 
anak usia dini, foto yang tanpa keterangan serta tidak adanya daya tarik (dapat dimasukkan slogan "Sekolah Untuk Semua") pada brosur maupun spanduk. Media online seperti website harus diperbaharui konten supaya ketika pencaharian tentang Sekolah Aluna selalu menampilkan yang barubaru baik dari segi foto kegiatan maupun informasi. Media sosial (facebook dan instagram) yang digunakan Sekolah Aluna sudah bagus namun bisa juga ditambakan konten acara seminar atau pelatihan khusus guru dan staf sekolah, supaya terlihat bahwa sekolah juga memberikan pelatihan dan bekal untuk para stafnya. Promosi berperan dalam menghasilkan penyampaian pesan yang baik kepada konsumen akan manfaat dan kelebihan suatu produk ataupun jasa sehingga dapat mempengaruhi calon konsumen/calon orang tua siswa untuk menyekolahkan anaknya di Sekolah Aluna. Namun, Sekolah Aluna harus sedikit membenahi pemasarannya dari segi media offline dan website supaya dapat meningkatkan jumlah calon orang tua siswa yang tertarik untuk menyekolahkan anak mereka ke Sekolah Aluna.

Bagian administrasi sekolah sebagai jembatan dari orang tua siswa kepada pihak internal sekolah (guru atau kepala sekolah) harus terus meningkatkan pengetahuan tentang produk layanan jasa yang ditawarkan sekolah serta penyampaian informasi dari orang tua murid kepada pihak internal sekolah melalui administrasi harus lengkap dan dicatat supaya tidak terjadi salahpaham pada salah satu pihak. Penyampaian informasi dari pihak internal sekolah kepada orang tua ataupun sebaliknya dilakukan secara informatif supaya informasi tersampaikan dengan baik dan tidak terjadi kesalahpahaman antara orang tua siswa kepada pihak internal sekolah. Ketika penyampaian layanan jasa terpenuhi dari pihak internal sekolah maka konsumen/orang tua siswa merasa puas dan mempunyai penilaian yang baik akan sekolah tersebut serta berdampak meningkatkannya jumlah siswa. Namun, Sekolah Aluna mengalami penurunan yang cukup signifikan ini disebabkan karena belum diperbaharui media promosi serta product knowledge yang harus ditingkatkan dari pihak administrasi sekolah. Penurunan ini dapat ditingkatkan salah satunya dengan meningkatan sarana dan prasarana yang dimiliki instansi tersebut. Sarana dan prasarana yang memadai, menunjang kegiatan sekolah, dan sebagai tolak ukur orang tua siswa dalam menentukan sekolah untuk buah hatinya. Selain itu, pemasaran juga berperan dalam meningkatnya konsumen/calon orang tua siswa dalam memilih sekolah untuk buah hati mereka.

Enam bauran promosi antara lain: periklanan (advertising), pemasaran langsung (direct marketing), promosi penjualan (sales promotion), penjualan personal (personal selling), pemasaran interaktif (interactive marketing), dan hubungan masyarakat (public relations). 8 Sekolah Aluna dalam membangun citra baik di masyarakat menggunakan dua bauran promosi yaitu periklanan (advertising), dan pendekatan public relations. Periklanan terlihat dari media promosi yang digunakan oleh Sekolah Aluna yaitu media offline (brosur, spanduk) dan online(website, media sosial: facebook, instagram). Iklan yang ditampilkan dalam mengiring minat calon orang tua siswa dalam memilih Sekolah Aluna.

Menurut Buchari Alma dalam Priansa ${ }^{9}$ menyatakan bahwa sejumlah tipe yang terkait dengan iklan, yaitu price advertising, yaitu iklan yang menonjolkan harga yang menarik. Sekolah Aluna memiliki penawaran yang sangat menarik sesuai dengan motto "Sekolah Untuk Semua" siapapun, kalangan apapun Pertama, semua boleh merasakan pendidikan di Sekolah Aluna. Kedua, brand advertising yaitu iklan yang memberikan kesan tentang namabrand kepada pembaca atau pendengarnya. Sekolah Aluna memperkenalkan dirinya sebagai sekolah Montessori hal ini tercermin pada brosur yang menyantumkan kegiatan Montessori yang dilakukan anak. Ketiga, quality advertising yaitu iklan yang mencoba menciptakan kesan bahwa produk yang direklamekan/diiklankan mempunyai mutu yang tinggi. Sekolah Aluna menciptakan bahwa produk sekolah itu memiliki fasilitas yang memadai seperti keterangan fasilitas yang dicantumkan pada brosur Sekolah Aluna. Keempat, product advertising yaitu iklan yang berusaha memengaruhi konsumen dengan faedah-faedah dari pemakaian suatu produk. Sekolah Aluna memengaruhi konsumen dengan sistem dan metode yang dijalankan sekolah tersebut, yaitu sistem inklusi dan metode Montessori. Kelima, institusional advertising yaitu iklan yang menonjolkan nama dari perusahaan dengan harapan agar konsumen mempunyai kesan mendalam tentang nama perusahaan tersebut. Brosur sudah menonjolkan nama dari Sekolah Aluna beserta yang dapat dihubungi. Keenam, yaitu prestige advertising yaitu iklan yang berusaha 
memberikan fashion pada suatu produk atau mendorong masyarakat mengasosiasikan produk tersebut dengan kekayaan atau kedudukan. Sekolah dengan metode Montessori dikala masyarakat umum terkenal cukup mahal, namun untuk Sekolah Aluna kata "mahal" hanya untuk keluarga menengah atas. Anak dari kalangan prasejahtera mendapatkan subsidi silang dari keluarga menengah atas.

Periklanan merupakan salah satu yang paling ditonjolkan dalam hal promosi Sekolah Aluna baik media secara online maupun offline. Media online digunakan dalam menghemat biaya promosi, seperti media sosial (facebook dan instagram) dapat digunakan oleh siapapun dan dimanapun. Website pun kurang digunakan dalam kegiatan promosi dikarena belum diperbaharui dalam kurun waktu 1 tahun belakang ini. Padahal kegiatan harian yang di update melalui media sosial dilakukan bukan hanya untuk diperlihatkan kepada orang tua siswa yang telah bersekolah di Sekolah Aluna namun juga untuk meningkatkan minat orang tua lain yang sedang mencari sekolah untuk anak usia dini untuk ikut bergabung di Sekolah Aluna. Informasi yang disampaikan melalui website dan media offline (brosur dan spanduk) kurang maksimal dikarenakan belum diperbaharui media tersebut sampai saat ini.

Selain itu promosi melalui periklanan, promosi yang digunakan oleh Sekolah Aluna adalah pendekatan hubungan masyarakat (public relations). Hubungan masyarakat (public relations) dilakukan oleh bagian administrasi Sekolah Aluna, bagian ini memberikan informasi yang dibutuh oleh orang tua tentang sekolah serta menjembatani antara orang tua dengan guru melalui media komunikasi massa yaitu whatsapp. Pendekatan public relations belum terlihat begitu menonjol karena perlunya pelatihan akan layanan jasa yang ditawarkan Sekolah Aluna baik secara sistem, metode pembelajaran maupun sarana dan prasarana yang akan didapatkan dari sekolah untuk para peserta didik. Komunikasi antar internal sekolah pun mesti ditingkatkan supaya tidak ada kesalahpahaman dalam memberikan infomasi kepada pihak eksternal sekolah (orang tua siswa/calon orang tua siswa). Sekolah Aluna hanya menggunakan dua bauran promosi yaitu periklanan dan pendekatan public relations dari enam bauran promosi yang dikemukan oleh Michael Ray dalam Morissan ${ }^{8}$ hal ini dapat menyebabkan terjadinya penurunan jumlah siswa serta berdampak kemerosatan brand image. Sekolah Aluna menggunakan dua bauran promosi disebabkan karena tidak adanya staf khusus dalam bagian promosi.

Baruzzi dalam Yunus ${ }^{17}$ menyebutkan bahwa untuk nilai sebuah brand, kegiatan public relations lebih penting daripada iklan. Semestinya Sekolah Aluna membangun nilai jual dengan meningkatkan pendekatan public relations. Hal ini public relations sebagai fasilitator antara konsumen dan pihak internal sekolah. Citra baik dari instansi pendidikan dapat dibangun dari sistem, metode pembelajaran, sarana prasarana serta seluruh pihak internal sekolah. Sekolah yang telah memiliki layanan jasa yang dibutuhkan perlu juga tempat yang strategis dalam membangun sekolah, biaya yang terjangkau, orang yang berkompeten dalam membangun sekolah supaya tercipta kenyamanan, kepuasan terhadap layanan yang diberikan. Hal-hal tersebut tidak akan diketahui oleh orang banyak tanpa adanya promosi yang dilakukan oleh pihak sekolah. Promosi yang dilakukan sekolah pun perlu memiliki staf khusus untuk menarik minat calon orang tua siswa. Setelah semua tercapai maka citra merek jasa layanan pendidikan Sekolah Aluna akan meningkatkan jumlah siswa serta berdampak baik terhadap nama baik sekolah. Sekolah Aluna merepresentasiksn sebagai sekolah dengan berbasis sistem dan metode pembelajaran yang dirancang untuk anak berkebutuhan khusus. Sistem dan metode yang diterapkan merupakan salah satu nilai jual dan ciri khas dari Sekolah Aluna. Sekolah untuk semua ini pun sudah cukup terkenal di lingkungan sekitar, walaupun saat ini Sekolah Aluna mengalami penurunan jumlah siswa.

Menurut hasil observasi dari peneliti, rasa kepercayaan terhadap Sekolah Aluna menurun dikarena informasi yang tersampaikan dari bagian administrasi kepada guru belum maksimal. Padahal bagian administrasi merupakan salah satu dari public relations Sekolah Aluna. Bagian administrasi yang memegang peranan dalam penyampaian informasi dari orang tua siswa kepada guru begitupun sebaliknya. Promosi diperlukan untuk membangun brand image di masyarakat serta dapat meningkatkan nilai jual dari layanan jasa atau produk. Promosi dilakukan dengan periklanan dan melalui pendekatan public relations. Iklan yang bertujuan dalam mempublikasikan kegiatan-kegiatan produk atau layanan jasa sedangkan public relations bertujuan dalam rangka menjual produk dengan pendekatan personal. 


\section{JIKOM \\ Jurnal Ilmiah Komunikasi}

Volume 12, No.01, Maret. 2020

Salah promosi periklanan adalah media sosial (facebook dan instagram) juga berperan penting dalam membangun brand image yang baik dalam mempromosikan Sekolah Aluna. Sekolah ini telah dikenal dan dinilai sebagai sekolah untuk semua, baik untuk kalangan atas, kalangan menengah, bahkan kalangan keluarga prasejahtera. Hal ini dilakukan Sekolah Aluna dalam rangka menyamakan ratakan pendidikan sekolah dini untuk semua kalangan dan semua anak baik reguler maupun anak berkebutuhan khusus (khususnya tunarungu). Brand image/citra merek yang positif tergambar dari kerjasama antara manajemen sekolah dengan orang tua siswa. Citra merek dapat dibangun dari berbagai hal, mulai dari sistem, metode pembelajaran, sarana dan prasarana, harga, lokasi, cara penyampain informasi, promosi yang dilakukan serta tanggapan positif dari orang tua yang telah merasakan layanan jasa sekolah tersebut. Brand image/citra positif dari layanan jasa akan meningkatkan jumlah siswa, kepercayaan serta loyalitas dari orang tua siswa.

\section{Kesimpulan}

Sekolah Aluna melakukan strategi pemasaran melalui periklanan yaitu brosur, spanduk dan media sosial: facebook dan instagram, website serta dengan pendekatan public relations dari manajemen Sekolah Aluna dalam penyampaian pesan/informasi kepada orang tua siswa. Pemasaran yang dilakukan dalam menjual sistem dan metode pembelajaran serta fasilitas yang ditawarkan oleh Sekolah Aluna.

Pendekatan public relations juga dilakukan oleh bagian administrasi Sekolah Aluna akan tetapi bagian administrasi yang berganti-ganti sumber daya manusia membuat penyampaian informasi belum tersampaikan secara maksimal dikarenakan kurangnya produk knowledge Sekolah Aluna. Hal ini menciptakan rasa kurang percaya orang tua siswa terhadap informasi yang disampaikan serta menyampaian informasi yang diberikan dari orang tua siswa kepada guru maupun sebaliknya terkadang belum tersampaikan dengan baik membuat penurunan jumlah siswa Sekolah Aluna.

Sekolah Aluna mengalami penurunan jumlah siswa hal ini berdampak pada menurunnya citra sekolah di masyarakat. Sekolah Aluna dalam meningatkan citra merek ini merancang strategi promosi supaya terjadi peningkatan jumlah siswa. Sekolah Aluna memiliki sistem dan metode yang sudah bagus, namun dalam penyampaian informasi kepada masyarakat masih kurang informatif, terlihat dari website, spanduk dan brosuryang belum diperbaharui. Sekolah Aluna hanya memberikan informasi melalui media sosial, facebook dan instagram.

\section{References}

1. Tirtarahardja, Umar. S.L. La Sulo. Pengantar Pendidikan. Jakarta: Penerbit Rineka Cipta;2013.

2. Syafril, Zelhendri Zen. Dasar-dasar Ilmu Pendidikan. Jakarta: Kencana. 2017

3. Stubbs, Sue. Inclusive Education Where There are Few Resources. Norwegia: idpnorway;2002.

4. Thompson. Jenny. Memahami Anak Berkebutuhan Khusus. Jakarta: PT. Gelora Aksara Pratama.;2014.

5. George. Dasar- dasar Pendidikan Anak Usia Dini (PAUD). Jakarta: PT. Indek. 2016.

6. Mulyana Deddy. Ilmu Komunikasi Suatu Pengantar. Bandung: Remaja Rosdakarya; 2015.

7. Rambat Lupiyoadi, A.Hamdani. Manajemen pemasaran jasa, Jakarta: Salemba Empat; 2006. Hal 120

8. Morissan. Periklanan: Komunikasi Pemasaran Terpadu. Jakarta: Kencana. 2015.

9. Priansa, Juni Donni. Komunikasi Pemasaran Terpadu. Bandung: Penerbit Pustaka Setia; 2017.

10. Swasty,Wirania. Branding Memahami dan Merancang Strategi Merek. Bandung: PT. Remaja Rosdakarya;2016.

11. Yusuf, A Muri. Metode Penelitian: Kuantitatif, Kualitatif, dan Penelitian Gabungan. Jakarta: Kencana.;2015.

12. Fitrah, Muh. Luthfiyah. Metodologi Penelitian; Penelitian Kualitatif, Tindakan Kelas \& Studi Kasus. Jawa Barat: CV. Jejak. 2017.

13. Mulyana, Deddy. Metodologi Penelitian Kualitatif Paradigma Baru Ilmu Komunikasi dan Ilmu Sosial Lainnya. Bandung: Remaja Rosdakarya.;2018.

14. Ilahi, Mohammad Takdir. Pendidikan inklusif Konsep \& Aplikasi. cetakan pertama. Yogyakarta: Ar-Ruzz media;2013.

15. Paramita, Vidya Dwina. Jatuh Hati Pada Montessori. Bandung: Mizan Media Utama; 2018. 


\section{JIKOM}

Jurnal Ilmiah Komunikasi

Volume 12, No.01, Maret. 2020

16. Wijaya. David. Pemasaran Jasa Pendidikan. Jakarta: PT. Bumi Aksara Group. 2016.

17. Yunus, Ulani. dkk. Advertising \& Branding. Jakarta: Edu Pustaka.;2017 